\title{
Rehabilitating Degraded Hardwood Stands on a Bottomland Terrace Site with Overstory Removal and Oak Enrichment Planting: 14-Year Results
}

\author{
Matthew G. Olson ${ }^{1,2}{ }^{*}$, Shaik Hossain ${ }^{3,4}$, Kyle Cunningham1, Matthew H. Pelkki1,2, \\ Chris Stuhlinger ${ }^{1}$ \\ ${ }^{1}$ Arkansas Forest Resources Center, University of Arkansas, Division of Agriculture, Monticello, AR, USA \\ ${ }^{2}$ College of Forestry, Agriculture, \& Natural Resources, University of Arkansas-Monticello, Monticello, AR, USA \\ ${ }^{3}$ Oak Ridge Institute for Science \& Education, Oak Ridge, TN, USA \\ ${ }^{4}$ USDA Forest Service, Southern Research Station, Monticello, AR, USA \\ Email: *olsonm@uamont.edu
}

How to cite this paper: Olson, M. G., Hossain, S., Cunningham, K., Pelkki, M. H., \& Stuhlinger, C. (2018). Rehabilitating Degraded Hardwood Stands on a Bottomland Terrace Site with Overstory Removal and Oak Enrichment Planting: 14-Year Results. Open Journal of Forestry, 8, 459-471.

https://doi.org/10.4236/ojf.2018.84029

Received: July 25, 2018

Accepted: September 10, 2018

Published: September 13, 2018

Copyright $\odot 2018$ by authors and Scientific Research Publishing Inc. This work is licensed under the Creative Commons Attribution International License (CC BY 4.0).

http://creativecommons.org/licenses/by/4.0/

\begin{abstract}
Exploitative harvesting can lower stand quality in the short term and diminish forest productivity over the long term. In 2003, a rehabilitation experiment was installed in a southern hardwood stand on a bottomland terrace site, degraded by periodic exploitative cutting, to test the effectiveness of overstory removal and oak enrichment planting for improving stand quality and composition. Overstory removal treatments included clearcutting, stand improvement partial cutting, and an uncut control. Overstory treatment units were either planted with Nuttall oak (Quercus texana) seedlings or not planted. We revisited this study in 2017 to assess the outcome of oak enrichment planting across levels of overstory removal. Results in year 14 indicated poor survival of planted oaks under all overstory removal treatments (14\% $24 \%)$ and minimal height growth $(0.3 \mathrm{~m}$ in 13 years $)$ in areas treated with partial cutting and in uncut areas. Growth performance of planted oaks was significantly enhanced by clearcutting $(\mathrm{p}<0.01)$. However, the overwhelming response of natural oak regeneration initiated by clearcutting trumped the contribution from enrichment planting on this low quality bottomland terrace site. Enrichment planting of Nuttall oak did not increase oak regeneration success in our study. The ineffectiveness of enrichment planting in this study was likely related to the shady understory of partially cut stands and intense competition in clearcuts. Additional treatments, such as pre-planting site preparation and post-planting release may be necessary for enhancing and maintaining competitiveness of planted red oak seedlings on similar sites.
\end{abstract}




\section{Keywords}

Southern USA Hardwoods, Supplemental Planting, Nuttall Oak, Quercus texana

\section{Introduction}

Timber harvesting motivated solely by immediate revenue can leave stands in poor condition. Not only can non-silvicultural practices, like high-grading and diameter-limit cutting, lower stand quality through reductions in log grade, but exploitative cuttings may also have long-term deleterious impacts on forest productivity resulting from regeneration of undesirable species, dysgenic effects of selectively removing superior genotypes, and increased vulnerability of the residual stand to disease (Kenefic et al., 2005; Nyland, 2005, 2016). In the absence of corrective action, it may take many years before stands degraded by exploitative practices can support a commercial forestry operation (Kenefic \& Nyland, 2005; Nyland, 2005). Silvicultural options are available to enhance stand quality of degraded stands for a variety of management objectives.

In forests with a history of high-grading, rehabilitation may be the first step in implementing a program of sustainable forest management. Rehabilitation treatments generally fall into three silvicultural categories: stand tending, regeneration cutting, or some combination of the two (e.g., multi-aged silviculture). The stand tending approach is to implement a partial cutting to deliberately remove lower quality trees or species from a stand while retaining trees of higher value (i.e., stand improvement), but without intentionally initiating a new cohort. The tending option assumes there is enough quality remaining in the degraded stand to retain in the first place. If the quality of the residual stand is too low to justify an improvement cutting, then one option is to start over by establishing a new stand using even-aged regeneration methods. Since high-grading can result in irregular residual stand conditions (Kenefic \& Nyland, 2005; Nyland, 2006), rehabilitation may require separate treatments in different parts of the same stand (Nyland, 2016). For example, stand tending and regeneration can be integrated using multi-aged approaches like the irregular shelterwood or single-tree selection methods. Although the need for rehabilitation of stands degraded by high-grading is widely acknowledged, there are surprisingly few experiments specifically designed to evaluate rehabilitation options (Kenefic et al., 2014).

Hardwood forests with an overstory oak component may be particularly vulnerable to degradation from high-grading. Because of its higher commercial value, oak sawtimber can be a target of exploitative harvesting in hardwood stands. Aside from an immediate reduction in log grade, high-grading of oak sawtimber may also diminish acorn production and lower oak regeneration po- 
tential. It is well known that oak regeneration potential is often negatively correlated with site quality, which is more directly related to increasing intensity of competition from non-oak species as site quality increases (Johnson et al., 2009). The higher quality often associated with bottomland hardwood sites suggests that many of these areas may be vulnerable to competitive displacement of oak species. Timber harvesting in bottomland hardwoods without considering the status of oak advance reproduction can favor the regeneration of undesirable species and further exacerbate difficulty in regenerating oak (Clatterbuck \& Meadows, 1993; Meadows \& Stanturf, 1997).

When an objective is to regenerate oak species, the presence and competitive status of oak advance reproduction is a main consideration when prescribing treatments. Artificial regeneration can be used to help address some of the challenges to accumulating competitive oak advance reproduction and may be implemented as a part of an integrated strategy to overcome the oak regeneration problem (Dey et al., 2008, 2012). Although direct seeding can be used to regenerate oaks, seedling planting is often recommended due to its lower risk of failure (Twedt \& Wilson, 2002; Lockhart et al., 2003; Motsinger et al., 2010). A lower-cost alternative to establishing a planted stand that may be attractive to landowners is to plant fewer nursery-grown seedlings in an attempt to bolster natural regeneration potential (i.e., enrichment planting).

In 2003, a rehabilitation experiment was installed in a southern hardwood stand on a low-quality bottomland terrace site degraded by sawlog harvesting to test the effectiveness of overstory removal and oak enrichment planting for improving stand quality and composition. Results after the first growing season (2004) indicated that overstory removal, which included clearcutting, stand improvement partial cutting, and an uncut control, did not affect survival or growth of post-harvest planted Nuttall oak (Quercus texana) seedlings. In this investigation, we revisited the rehabilitation experiment in the $14^{\text {th }}$ year after enrichment planting. The main purpose of this investigation was to assess performance of a Nuttall oak enrichment planting under alternative overstory removal treatments with an emphasis on oak regeneration success after clearcutting on a low-quality bottomland site.

\section{Methods}

\subsection{Site Description}

The study is located at the University of Arkansas Division of Agriculture's Pine Tree Research Station (PTRS) in St. Francis County, Arkansas, USA (Figure 1; $\left.35^{\circ} 06^{\prime} 26.45^{\prime \prime} \mathrm{N}, 90^{\circ} 55^{\prime} 19.74^{\prime \prime} \mathrm{W}\right)$. The climate at PTRS is humid subtropical with a 30 -year average annual temperature and precipitation of $16^{\circ} \mathrm{C}$ and $127 \mathrm{~cm}$, respectively. The PTRS falls in the Lower Mississippi Alluvial Valley (LMAV); a physiographic region characterized by low topographic relief and wet soil conditions. Locally, the soils are influenced by the Crowley's Ridge loessial deposit (Gray, 1966). Soils of the study area are classified mainly into Calloway silt loam 


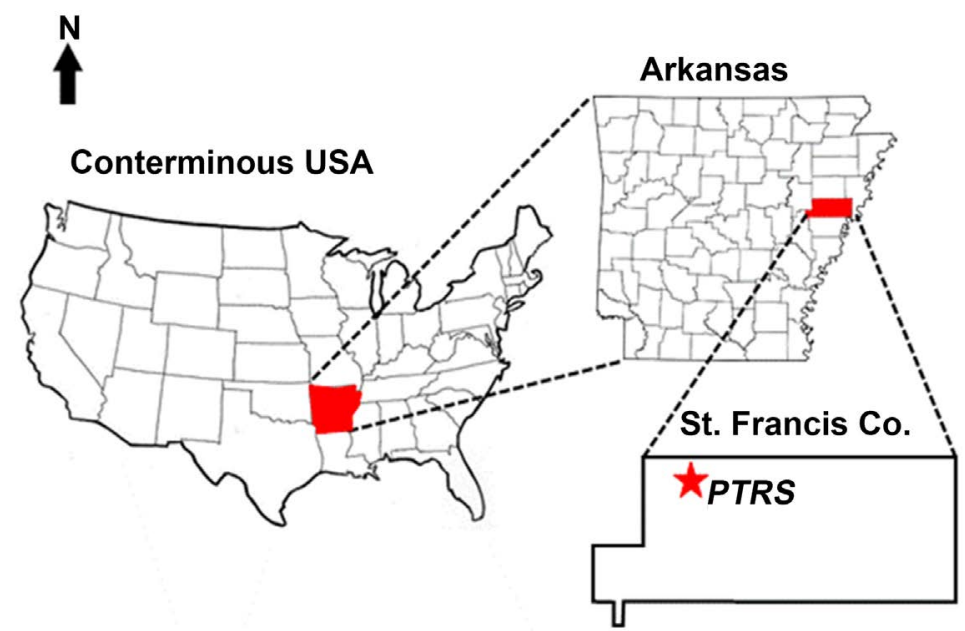

Figure 1. Location of Pine Tree Research Station (PTRS) in St. Francis County, Arkansas, USA.

and Calhoun silt loam series (Gray, 1966). The natural drainage class of these soils ranges from somewhat poorly to poorly drained. However, the site is located on a terrace position near a tributary of the L'Anguille River and rarely experiences flooding. Site index (base age of 50 years) for the Calloway soil series, the dominant soil type, is $24 \mathrm{~m}$ for both cherrybark oak (Quercus pagoda) and water oak (Quercus nigra), indicating a low-productivity site for bottomland red oak species.

The study is embedded in a 53-ha natural hardwood stand on a bottomland terrace site with a history of partial harvesting of sawtimber. Prior to this study (2003), mean basal area (BA) of sawtimber-sized trees (Diameter at breast height $(\mathrm{DBH}) \geq 24.4 \mathrm{~cm}$ ) was $13.4 \pm 5.1 \mathrm{~m}^{2}$ per ha (standard error). The sawtimber component of this stand was heavily dominated by oak species. Post oak (Quercus stellata), cherrybark oak, willow oak (Quercus phellos), water oak, white oak (Quercus alba), and southern red oak (Quercus falcata) accounted for $42.4 \% \pm$ $6.1 \%, 19.6 \% \pm 3.9 \%, 11.4 \% \pm 4.5 \%, 5.8 \% \pm 2.2 \%, 3.6 \% \pm 2.0 \%$, and $0.7 \% \pm 0.7 \%$ of sawtimber BA, respectively. Hickory species (Carya spp.), elm species (Ulmus spp.), and loblolly pine (Pinus taeda) comprised $10.5 \% \pm 2.9 \%, 5.1 \% \pm 2.0 \%$, and $0.8 \% \pm 0.8 \%$ of sawtimber $\mathrm{BA}$, respectively.

\subsection{Study Design}

The experiment was installed in 2003-2004 to test overstory removal treatments and oak enrichment planting for rehabilitating degraded hardwood stands. Three levels of overstory removal and two levels of enrichment planting were combined to create 6 factorial combinations with each replicated four times. Treatment combinations were randomly assigned to $24,0.8$-ha treatment units (i.e., completely randomized design). The overstory treatments implemented were clearcutting, stand improvement partial cutting (hence, partial cutting), and a no-cut control (i.e., no additional cutting). Harvesting took place in Octo- 
ber-December 2003. In early March of 2004, overstory treatment units were either planted with nursery-grown oak seedlings or left unplanted.

Clearcutting was implemented as a complete overstory removal of merchantable timber followed by felling of all sub-merchantable trees $>2.5 \mathrm{~cm} \mathrm{DBH}$. The harvest prescription for the partial cutting treatment was to deliberately remove the lower quality trees and species while retaining adequate overstory stocking. An additional objective of this treatment was to improve understory light mainly for accumulating competitive oak advance reproduction. Mean sawtimber BA removed in the partial cut was $2.4 \pm 0.6 \mathrm{~m}^{2}$ per ha. Similar to pre-treatment composition, sawtimber post oak and cherrybark oak dominated partial cut stands immediately after harvest $\left(5.3 \pm 1.9 \mathrm{~m}^{2}\right.$ per ha and $3.9 \pm 1.1 \mathrm{~m}^{2}$ per ha, respectively). Midstory trees (10.2 $-24.4 \mathrm{~cm} \mathrm{DBH})$ on average made up $4.4 \pm 0.6$ $\mathrm{m}^{2}$ per ha in partial cuts shortly after harvest. Harvest removal in both treatments was greatest for oak species.

Prior to harvest, a single 0.08 -ha fixed-radius plot was established at the center of each overstory treatment unit for monitoring natural stand dynamics and the response of planted trees. The enrichment planting established 1-0 bare-root Nuttall oak seedlings planted by hand within the 0.08 -ha monitoring plots. Nuttall oak was selected largely because of excessively wet conditions encountered at the study site around the time of study establishment, but also due to limited availability of other species. The Arkansas Forestry Commission (AFC) provided the seedlings, which were grown at AFC's nursery in Baucum, AR. The original plan was to plant 20 seedlings per plot on a $6.3 \mathrm{~m} \times 6.3 \mathrm{~m}$ spacing ( 250 per ha), but difficulty in planting around logging slash and skidder ruts restricted the number of seedlings planted per plot to as few as 12 (150 per ha) in some units.

\subsection{Analytical Approach}

In July 2017, we revisited monitoring plots in 16 units representing four of six original treatment combinations: planted clearcuts, unplanted clearcuts, planted partial cuts, and planted controls. Since we were interested in comparing planted seedling performance in relation to overstory treatment, we decided to exclude unplanted controls and partial cuts. The species and DBH of all woody stems $\geq$ $8.9 \mathrm{~cm} \mathrm{DBH}$ rooted within each plot were recorded. Planted Nuttall oaks were also revisited to assess survival and growth out to the $14^{\text {th }}$ season. The ground line diameter (GLD), DBH, and total height were recorded for each live planted tree. In both planted and unplanted clearcuts, the competitive status of natural and planted oaks captured within the 0.08 -ha permanent plots $(\mathrm{DBH} \geq 8.9 \mathrm{~cm}$ ) was determined. Each recorded oak was assigned to one of three categories: free-to-grow, intermediate, and overtopped. Following Belli et al. (1999), trees as tall as or taller than immediate competitors and receiving direct sunlight from above were recorded as free-to-grow, trees with a crown receiving direct sunlight only on the terminal leader were recorded as intermediate, and trees with direct overhead competition were recorded as overtopped.

Analysis of variance (ANOVA) was used to assess the effect of overstory re- 
moval on performance of planted Nuttall oak. A preliminary analysis of initial seedling height and GLD recorded immediately after planting revealed no differences in seedling size between the treatments. Therefore, analysis based on relative growth rates was not necessary for this study. The survival and actual size (diameter and height) of planted trees were averaged at the unit level and served as the response variables. Data were submitted to a mixed-model ANOVA for a completely randomized design (Proc Mixed; SAS 9.4). Residuals were checked for normality and equal variance. Since residual variance met model assumptions, there was no need for transformation. Means were compared using Tukey's Honestly Significant Difference. T-tests were used for evaluating the efficacy of enrichment planting toward enhancing oak regeneration success in clearcuts. This was accomplished by determining the contribution of planted Nuttall oak to total oak regeneration (i.e., oaks originating from all sources) by competitive status class and for all classes combined. T-tests were also run using SAS 9.4. Statistical significance was assessed at the 0.05 level $(\mathrm{p}<0.05)$.

\section{Results}

\subsection{Overstory Structure and Composition}

At year 14, mean total BA of stems $\geq 8.9 \mathrm{~cm} \mathrm{DBH}$ was $11.0 \pm 0.6 \mathrm{~m}^{2}$ per ha, $8.2 \pm$ $2.4 \mathrm{~m}^{2}$ per ha, $20.4 \pm 1.5 \mathrm{~m}^{2}$ per ha, and $22.5 \pm 2.8 \mathrm{~m}^{2}$ per ha in unplanted clearcuts, planted clearcuts, planted partial cuts, and planted controls, respectively (Figure 2). In clearcuts, oaks were a major component of all size classes, while, in partial cuts and controls, oak dominance was mainly restricted to larger size classes. Red oak species dominated young stands in clearcuts. The density of planted oaks $\geq 8.9 \mathrm{~cm} \mathrm{DBH}$ in clearcuts averaged $47 \pm 5$ trees per ha. Planted tree densities in partial cuts and controls averaged $62 \pm 18$ trees per ha and $47 \pm$ 18 trees per ha, respectively; none of which were $\geq 8.9 \mathrm{~cm} \mathrm{DBH}$. Hickory and elm species were abundant in smaller size classes under all treatments and dominated the low end of the diameter distribution of partial cuts and controls.

\subsection{Planted Oak Survival and Growth}

Treatment was not a significant factor $(\mathrm{p}=0.36)$ in ANOVA models of planted Nuttall oak survival in the $14^{\text {th }}$ growing season. Mean survival in 2017 was $24.5 \%$ $\pm 1.5 \%, 21.6 \% \pm 6.9 \%$, and $14.4 \% \pm 5.0 \%$ in clearcutting, partial cutting, and control treatments, respectively (Figure 3(a)). Treatment was a significant factor in the ANOVA model for GLD, DBH, and height in 2017 ( $\mathrm{p}<0.01$ ). Mean separation revealed that planted Nuttall oak in clearcuts had significant larger GLD (Figure 3(b)), DBH (Figure 3(c)), and height (Figure 3(d)) than in other treatments.

\subsection{Enrichment Planting in Clearcuts}

According to t-tests, relative density of oaks $\geq 8.9 \mathrm{~cm} \mathrm{DBH}$ did not differ between planted $(65.6 \% \pm 3.7 \%)$ and unplanted $(61.0 \% \pm 18.7 \%)$ clearcuts 

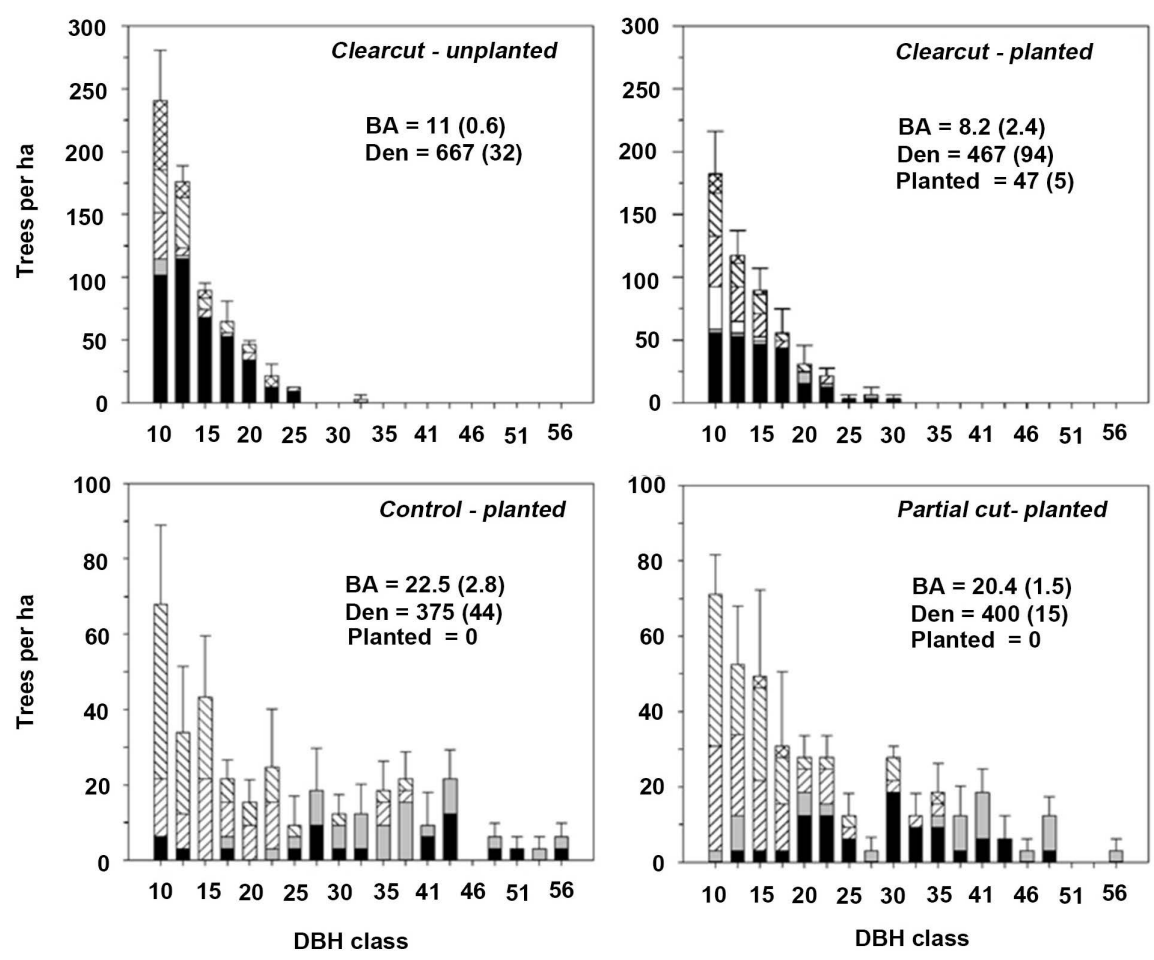

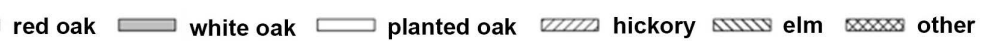

Figure 2. 2017 diameter distributions of the four rehabilitation treatments subdivided into six species groups. Inset data are estimates of mean basal area (BA) in $\mathrm{m}^{2}$ per ha, mean stem density (Den) in trees per ha, and mean density of planted trees (Planted) in trees per ha. Error bar and number in parentheses is equal to 1 standard error.

$(\mathrm{p}=0.66)$. The absolute density of oaks in unplanted clearcuts $(410 \pm 69$ trees per ha) was statistically comparable to that observed in planted clearcuts (306 \pm 62 trees per ha) $(\mathrm{p}=0.30$; Figure 4$)$, despite a large nominal difference in mean densities. No differences in the densities of free-to-grow (FTG; $p=0.41$ ), intermediate ( $\mathrm{p}=0.10)$, or overtopped $(\mathrm{p}=0.12)$ oaks were detected (Figure 4$)$. On average, there were $269 \pm 32$ FTG oaks per ha and $231 \pm 34$ FTG oaks per ha in unplanted and planted clearcuts, respectively. Planting contributed $22 \pm 3$ FTG oaks per ha on average. The combined density of FTG and intermediate oaks also did not differ $(\mathrm{p}=0.22)$ between planted and unplanted clearcuts $(284 \pm 59$ and $405 \pm 64$ trees per ha, respectively). Red oak species dominated FTG and intermediate classes of oak species developing in clearcuts.

\section{Discussion}

Survival of planted Nuttall oak was low and comparable among treatments in the $14^{\text {th }}$ growing season after harvesting on this bottomland terrace site, leaving 47 - 62 planted oaks per ha across treatments. Others studies found that early survival of planted Nuttall oak was largely unaffected by residual overstory stocking (Chambers \& Henkel, 1989; Ware \& Gardiner, 2004). However, poor survival in the partial cut and control treatments after nearly 15 years was 

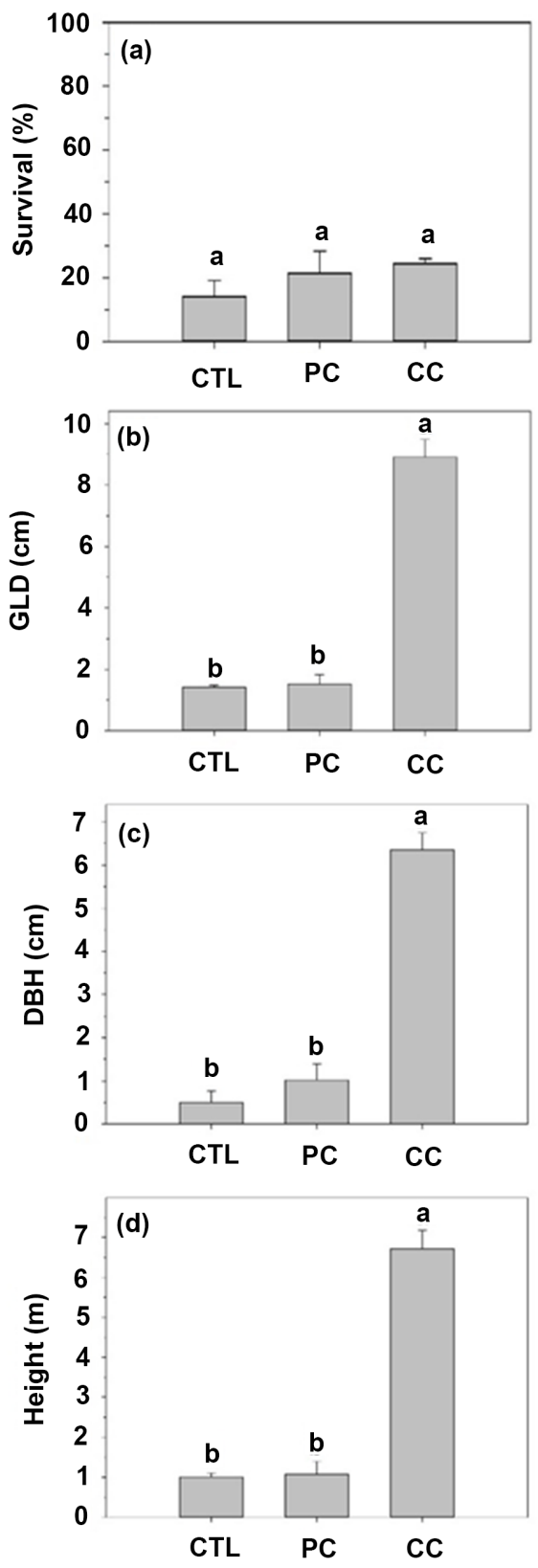

Figure 3. Treatment comparison of mean survival (a), mean ground line diameter (GLD (b), mean diameter at breast height (DBH) (c), and mean height (d) of planted Nuttall oak in the $14^{\text {th }}$ year after planting. Treatment abbreviations are: CTL for control, PC for partial cut, and CC for clearcut. Means with the same letter are not statistically different ( $\mathrm{p}>$ 0.05). Error bar is equal to 1 standard error.

was expected given Nuttall oak's lower shade tolerance (Filer, 1990). After 15 years beneath a dense canopy, there were few surviving natural Nuttall oak seedlings in a Mississippi study (Johnson, 1975). In our study, there also was no difference in seedling size between partial cut and control treatments, suggesting that the lower intensity partial harvest treatment did not enhance seedling 


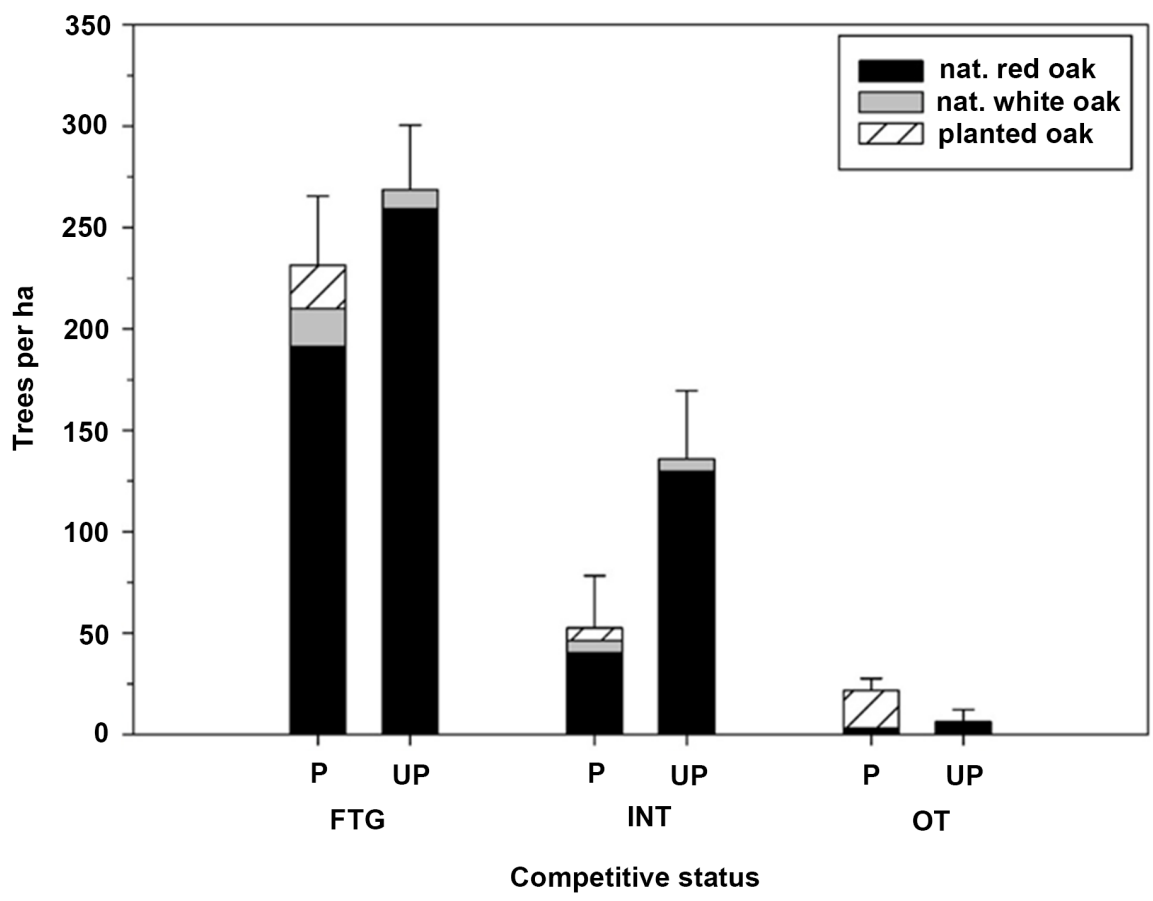

Figure 4. 2017 mean trees per ha of all oaks in planted (P) and unplanted (UP) clearcuts subdivided into species group (natural red, natural white, and planted oaks) and three competitive status categories: free-to-grow (FTG), intermediate (INT), and overtopped (OT). Error bars are equal to 1 standard error.

growth performance after 14 years. Nuttall oak reproduction can endure 5 - 10 years in dense shade, but with little to no height growth (Johnson, 1975). In an underplanting study in Louisiana, height growth of planted Nuttall oak seedlings did not increase under less than a $24 \%$ reduction in overstory basal area (Chambers \& Henkel, 1989). In this study, partial cutting removed less than $20 \%$ of sawtimber basal area, which likely did not provide enough of an amelioration of the understory light environment to enhance Nuttall oak performance. If residual stand density from partial cutting had been reduced to a shelterwood level basal area of $11.6 \mathrm{~m}^{2}$ per ha, an improved sunlight environment and greater potential for increased survival and seedling development would have existed in that treatment (Cunningham et al., 2011). Intense competition from herbaceous and woody competitors may have impacted survival and seedling development in the high-sunlight, clearcut treatments.

Planted Nuttall oak were much larger in clearcuts than the other treatments in year 14. This result was not surprising given the open overstory structure of the clearcut compared to the other treatments. Johnson and Krinard (1989) also observed red oaks were substantially larger in clearcuts than a selection cut stand 15 years after cutting in a Mississippi bottomland hardwood stand. Research in Mississippi also found that the tallest Nuttall oak averaged $7.6 \mathrm{~m}$ tall in 15-year-old clearcuts (Johnson \& Krinard, 1989). In our study, Nuttall oak in clearcuts averaged $6.7 \mathrm{~m}$ tall with the height of FTG and intermediate Nuttall oak averaging $8.6 \mathrm{~m}$. Interestingly, this suggests Nuttall oak, a species considered 
best suited to wetter sites associated with active floodplains (Johnson, 1975), grew well in clearcuts on this terrace site. Nuttall oak is a fast-growing species with seedlings that can grow rapidly in canopy openings (Filer, 1990). Rapid growth of Nuttall oak in the clearcuts of this study suggests this species is opportunistic in open conditions, even on a presumably sub-optimal growing site.

When adequate oak advance reproduction and/or stump sprouting potential exists prior to harvest, clearcutting can be an effective method for regenerating oak on bottomland sites (Clatterbuck \& Meadow, 1993; Meadows \& Stanturf, 1997). It has been suggested that 185 - 247 FTG oak stems per ha (75 - 100 per acre) may be sufficient to assure full stocking of oak species on southern bottomland sites (Clatterbuck \& Hodges, 1988; Belli et al., 1999). Based on this criterion for assessing oak regeneration success, both planted and unplanted clearcuts supported an adequate density of FTG natural oak stems. Our results indicate that natural oak regeneration may be sufficient in ensuring a future component of oak in regenerating clearcuts at our study site. The numerous sprout groups of FTG oaks in clearcuts, mainly cherrybark oak, willow oak, and water oak (personal observation), suggest that stump and seedling sprouting were major contributors to oak regeneration success. Stands treated with clearcutting in this study exhibited a high regeneration potential for oak, which appeared to be a function of the pre-harvest sprouting capacity of red oaks and possibly an adequate density of competitive oak advance reproduction. Since we lack data on pre-harvest status of advance reproduction, we are unable to conclude on the contribution of oak advance reproduction to oak regeneration success after clearcutting.

Seedling planting can help to overcome difficulties in regenerating oak (Dey et al., 2008, 2012), which is why it was evaluated as a rehabilitation option in this study. Our enrichment planting of Nuttall oak did not improve oak regeneration success in stands treated with either partial cutting or clearcutting. In partially cut stands, the average height of planted oaks increased by only $0.33 \mathrm{~m}$ in the last 13 years and no planted trees $\geq 8.9 \mathrm{~cm} \mathrm{DBH}$ were recorded at year 14 . Meanwhile, enrichment planting added on average only 22 FTG oaks per ha to young stands developing in clearcuts. Failure to establish oak species through artificial regeneration has been attributed to a variety of factors (Dey et al., 2008). The ineffectiveness of enrichment planting in this study is likely related to the shady understory of partially cut stands and intense competition in clearcuts.

Modifications to the original treatment prescriptions, including implementation of extra treatments, may have improved survival and growth of planted Nuttall oak. Pre-planting site preparation and subsequent release (i.e., cleaning and thinning) can benefit planted oak after a complete overstory removal (Dey et al., 2008). Post-planting release may be needed to maintain FTG Nuttall oak on sites with aggressive competition from woody species (Johnson, 1975). Ware and Gardiner (2004) concluded that early competition control did not enhance planted Nuttall seedling survival or growth in a partial harvest, but did increase the proportion of FTG trees three years after treatment. Midstory removal is 
commonly recommended to ameliorate understory light for oak advance reproduction (Lorimer et al., 1994; Lhotka \& Loewenstein, 2009). Planted oaks in partial cuts likely would have benefited from a heavier initial harvest that also removed the midstory layer as well as a second partial overstory removal during the 14-year study period. Midstory removal and underplanting a few seasons in advance of clearcutting also may have enhanced planted seedling performance by promoting seedling acclimation to the planting site prior to the onset of intense competition after overstory release.

Overstory treatments appear to have initiated divergent patterns of succession at the study site. White oak and red oak species dominated the overstory prior to treatment. Fourteen years after clearcutting, red oak species were the dominant component in these young stands, suggesting that clearcutting maintained oak species but shifted stand composition from a mix of white and red oak species to red oak dominance. Red oaks species can have a growth advantage over white oaks under lower canopy densities (Vickers et al., 2014). In areas treated with partial cutting and in controls, the larger size classes were still dominated by oaks, while hickory and elm species dominated the smaller size classes. This pattern could portend a longer-term loss of oak dominance and a shift toward hickory and elm. Lack of planted tree ingrowth into the midstory of partial cuts and controls suggests enrichment planting has done little to reverse the successional trend.

\section{Conclusion}

Enrichment planting of Nuttall oak did not increase oak regeneration success in our study. The partial overstory removal treatment was too light to ameliorate the understory environment for moderately shade intolerant species like Nuttall oak. In clearcuts, the overwhelming response of natural oak regeneration trumped the contribution from enrichment planting on this low-quality bottomland terrace site. This highlights the importance of a pre-harvest assessment of oak regeneration potential to inform whether enrichment planting is warranted in the first place. Additional treatments, such as pre-planting site preparation and post-planting release may be necessary for enhancing and maintaining competitiveness of planted oak seedlings on similar sites.

\section{Acknowledgements}

We thank the 2017 summer field crew for their hard work and dedication to collecting quality data. This work was supported by the USDA National Institute of Food and Agriculture, McIntire-Stennis Project (Accession \#: 1010629).

\section{Conflicts of Interest}

The authors declare no conflicts of interest regarding the publication of this paper.

\section{References}

Belli, K. L., Hart, C. P., Hodges, J. D., \& Stanturf, J. A. (1999). Assessment of the Regene- 
ration Potential of Red Oaks and Ash on Minor Bottoms of Mississippi. Southern Journal of Applied Forestry, 23, 133-138.

Chambers, J. L., \& Henkel, M. W. (1989). Survival and Growth of Natural and Artificial Regeneration in Bottomland Hardwood Stands after Partial Overstory Removal. In J. H. Miller (Ed.), Proceedings of the Fifth Biennial Southern Silvicultural Research Conference (pp. 277-283). General Technical Report SO-74. USDA Forest Service, Southern Forest Experiment Station.

Clatterbuck, W. K., \& Hodges, J. D. (1988). Development of Cherrybark Oak and Sweet Gum in Mixed, Even-Aged Bottomland Stands in Central Mississippi, USA. Canadian Journal of Forest Research, 18, 12-18. https://doi.org/10.1139/x88-003

Clatterbuck, W. K., \& Meadows, J. S. (1993). Regenerating Oaks in the Bottomlands. In: D. L. Loftis, \& C. E. McGee (Eds.), Oak Regeneration: Serious Problems, Recommended Solutions: Symposium Proceedings (pp. 184-195). General Technical Report SE-84. USDA Forest Service, Southeastern Forest Experiment Station.

Cunningham, K. K., Peairs, S. E., Ezell, A. W., Belli, K. L., \& Hodges, J. D. (2011). Understory Light Conditions Associated with Partial Overstory Removal and Midstory/Understory Control Applications in a Bottomland Hardwood Forest. Forests, 2, 984-992. https://doi.org/10.3390/f2040984

Dey, D. C., Gardiner, E. S., Schweitzer, C. J., Kabrick, J. M., \& Jacobs, D. F. (2012). Underplanting to Sustain Future Stocking of Oak in Temperate Deciduous Forests. New Forest, 43, 955-978. https://doi.org/10.1007/s11056-012-9330-Z

Dey, D. C., Jacobs, D. F., McNabb, K., Miller, G., Baldwin, V., \& Foster, G. (2008). Artificial Regeneration of Major Oak (Quercus) Species in the Eastern United States-A Review of the Literature. Forest Science, 54, 77-106.

Filer, T. H. (1990). Quercus nuttallii Palmer-Nuttall Oak. In R. M. Burns, \& B. H. Honkala (Coords.), Silvics of North America Volume 2: Hardwoods (pp. 1359-1365). Agricultural Handbook. USDA Forest Service.

Gray, J. L. (1966). Soil Survey: St. Francis County, Arkansas. US Soil Conservation Service.

Johnson, P. S., Shifley, S. R., \& Rogers, R. (2009). The Ecology and Silviculture of Oaks (2nd ed.). New York: CABI Publishing. https://doi.org/10.1079/9781845934743.0000

Johnson, R. L. (1975). Natural Regeneration and Development of Nuttall Oaks and Associated Species. Report SO-104. USDA Forest Service, Southern Forest Experiment Station.

Johnson, R. L., \& Krinard, R. M. (1989). Survival and Growth of Nuttall Oak Seedlings Following Selection Cutting-28-Year Remeasurement. Southern Journal of Applied Forestry, 13, 43-46.

Kenefic, L. S., \& Nyland, R. D. (2005). Diameter-Limit Cutting and Silviculture in Northeastern Forests: A Primer for Landowners, Practitioners, and Policymakers. NA-TP-02-05. USDA Forest Service.

Kenefic, L. S., Bataineh, M., Wilson, J. S., Brissette, J. C., \& Nyland, R. D. (2014). Silvicultural Rehabilitation of Cutover Mixedwood Stands. Journal of Forestry, 112, 261-271. https://doi.org/10.5849/jof.13-033

Kenefic, L. S., Sendak, P. E., \& Brissette, J. C. (2005). Comparison of Fixed Diameter-Limit and Selection Cutting in Northern Conifers. Northern Journal of Applied Forestry, 22, 77-84.

Lhotka, J. M., \& Loewenstein, E. F. (2009). Effect of Midstory Removal on Understory Light Availability and the 2-Year Response of Underplanted Cherrybark Oak Seedlings. 
Southern Journal of Applied Forestry, 33, 171-177.

Lockhart, B. R., Keeland, B., McCoy, J., \& Dean, T. J. (2003). Comparing Regeneration Techniques for Afforesting Previously Farmed Bottomland Hardwood Sites in the Lower Mississippi Alluvial Valley, USA. Forestry, 76, 169-180.

https://doi.org/10.1093/forestry/76.2.169

Lorimer, C. G., Chapman, J. W., \& Lambert, W. D. (1994). Tall Understory Vegetation as a Factor in the Poor Development of Oak Seedlings beneath Mature Stands. Journal of Ecology, 82, 227-237. https://doi.org/10.2307/2261291

Meadows, J. S., \& Stanturf, J. A. (1997). Silvicultural Systems for Southern Bottomland Hardwood Forests. Forest Ecology and Management, 90, 127-140. https://doi.org/10.1016/S0378-1127(96)03898-4

Motsinger, J. R., Kabrick, J. M., Dey, D. C., Henderson, D. E., \& Zenner, E. K. (2010). Effect of Midstory and Understory Removal on the Establishment and Development of Natural and Artificial Pin Oak Advance Reproduction in Bottomland Forests. New Forest, 39, 195-213. https://doi.org/10.1007/s11056-009-9164-5

Nyland, R. D. (2005). Diameter-Limit Cutting and Silviculture: A Comparison of Long-Term Yields and Values for Uneven-Aged Sugar Maple Stands. Northern Journal of Applied Forestry, 22, 111-116.

Nyland, R. D. (2006). Rehabilitating Cutover Stands: Some Ideas to Ponder. In L. S. Kenefic, \& R. D. Nyland (Eds.), Proceedings of the Conference on Diameter-Limit Cutting in Northeastern Forests (pp. 47-51). General Technical Report NE-342, USDA Forest Service, Northeastern Forest Experiment Station.

Nyland, R. D. (2016). Silviculture: Concepts and Applications (3rd ed.). Long Grove, IL: Waveland Press.

Twedt, D. J., \& Wilson, R. R. (2002). Development of Oak Plantations Established for Wildlife. Forest Ecology and Management, 162, 287-298.

https://doi.org/10.1016/S0378-1127(01)00523-0

Vickers, L. A., Larsen, D. R., Knapp, B. O., Kabrick, J. M., \& Dey, D. C. (2014). The Impact of Overstory Density on Sapling Height Growth in the Missouri Ozarks: Implications for Interspecific Differentiation during Canopy Recruitment. Canadian Journal of Forest Research, 44, 1320-1330. https://doi.org/10.1139/cjfr-2014-0237

Ware, B. P., \& Gardiner, E. S. (2004). Partial Cutting and Establishment of Artificial Nuttall Oak Regeneration in the Mississippi Alluvial Plain. In K. F. Conner (Ed.), Proceedings of the 12th Biennial Southern Silviculture Research Conference (pp. 587-591). General Technical Report SRS-71, USDA Forest Service, Southern Research Station. 